\title{
Juridical Decrees in Nisa Sura
}

\author{
Roya Bigonah $^{1} \&$ Ahmad Shafaemehr ${ }^{1}$ \\ ${ }^{1}$ Department of Islamic Law and Jurisprudence, Ardabil Branch, Islamic Azad University, Ardabil, Iran \\ Correspondence: Ahmad Shafaemehr, Department of Islamic Law and Jurisprudence, Ardabil Branch, Islamic \\ Azad University, Ardabil, Iran. E-mail: a_shafaeimehr@yahoo.com
}

Received: July 12, $2016 \quad$ Accepted: August 18, $2016 \quad$ Online Published: September 29, 2016
doi:10.5539/jpl.v9n8p73
URL: http://dx.doi.org/10.5539/jpl.v9n8p73

\begin{abstract}
Quran is the primary source for recognition of religious teachings, jurisprudence decrees and social and personal relationships and at the same time, it is the perfect source. Quran is definite in terms of issuance and fundamentalists considered authority for the Quranic verses. Major part of Quranic verses indicate principles of Islam doctrine, for example verses about the God, hereafter, heaven and hell, reward and punishment indicate beliefs. Another part of verses express the ethical aspect and relationships among Muslims. For example, verses related to the forgiveness, avoiding lie, gossip and hypocrisy and the importance of piety are Quranic ethical verses. Third part of the verses which are less than two other parts are verses related to the decrees. Nisa is one of juridical Sura in the Quran and it has numerous juridical decrees in itself. It is the fourth Sura of Quran. In fact, the major theme of this Sura is legislation. It seems that one point that should be considered in the inference and extraction of decree verses is the abrogating and abrogated knowledge of verses and whether they revealed in the Mecca or Medina. Otherwise, abrogated verses may use as the juridical decree for inference and a false decree issues. This research seeks to study the juridical decrees of Nisa Sura.
\end{abstract}

Keywords: Quran, jurisprudence, Nisa Sura, woman, heritage

\section{Introduction}

Certainly, one of the most important sources of decrees and practical instructions in Islam is Quran which are called "decree verses". Although religious and juridical decree includes beliefs and ethical decrees and even all dos and don'ts that have subjective aspect are called religious decree, but what is popular among Islamic scholars in this case is the practical decrees about the worship, transactions, demeanors and punishments for regulating the relationship between servants and God that all of them are collectively called religious and juridical decrees. Therefore, juridical decree is a decree that has command form in the practice. On the other hand, other legislative discussions in Quran is not classified or based on the subject with expressing all characteristics and details like law or juridical books. One of the Sura that God has expresses various decrees in it for Muslims is Nisa Sura. This is the fourth Sura of Quran which is revealed in the Medina and has 177 verses. This Sura, in terms of number of words and letters, is the second long Sura in Quran after Baghareh (Makarem Shirazi, 1995).

Holy Islam prophet (peace be upon him) stated that "one who reads the Nisa Sura has given almsgiving in the way of God like the Muslim who inherits according to this Sura and also he has the reward of someone who has released a slave (Noori, p. 338). Since various decrees about the rights of women are presented in this Sura, it is called Nisa (women) (Makarem Shirazi, 1995).

This Sura begins with the subject of piety and the blessing of being and creation ${ }^{1}$ (4: 1) and ends with a financial problem about the division of heritage and knowledge of God about the benefits of decrees (4: 177). This means that it begins with the piety and spirituality problem and ends with an economic issue.

In addition to this fact the Nisa Sura is about women and it expresses the rights of women, it has numerous juridical decrees. Main theme of this Sura is legislation, especially about the women and it has numerous juridical decrees and we can call it one of the juridical Sura in Quran, especially exclusive jurisprudence for women and therefore, it is called Nisa (women). General decrees in this Sura include: social and human rights and decrees for women, financial and economic rights and decrees of women and their economic independence,

1. O mankind! Be careful of your duty to your Lord 
confidant and stranger, polygamy and observing the rights of women in this case, some decrees about marriage, decrees about orphans, heritage and inheritance division among the heirs and relatives, some juridical decrees about the properties and assets, trade decrees, murder decree, compensation, fear prayer and war prayer decrees, incapacity and incapable people decree i.e. those who are forbidden to manipulate their assets religiously, salves' decree including marriage, non-compliance and conflict between husband and wife and resolving the family conflicts and divorce (Tabatabaee, 2005; Makarem Shirazi, 1995). Regarding various decrees expressed in the Nisa Sura, this paper seeks to study these juridical decrees.

\section{Position of Woman in the Quran}

In Holy Quran, three Sura are allocated and named for women:

1) Nisa Sura which is called "Nisa-al-kobra" i.e. great Sura for women.

2) Talaq (divorce) Sura, i.e. the $65^{\text {th }}$ Sura of Quran which is called little Sura for women.

3) Maryam Sura, i.e. the $19^{\text {th }}$ Sura of Quran which is called after the name of "Mary", mother of Jesus (peace be upon him).

Although some Sura in Quran have the name of prophets, but there is no Sura with the general title "men" or like and this indicated the high position of worthy and pious women in Islam and their real position. Before Islam and revelation of Quran, human personality of women in the Arab community was under question and women even were deprived of their absolute rights and even considered inferior and shameful (Qasemi, 2011). by revelation of Holy Quran, it fought against this cruel and ugly social culture and by explaining the high position of woman in the Islam and by narrating the story of pious and worthy women and celebrating their high position in the Quran and by legislating in order to provide their interests and rights, highlighted the personality of woman in the society and revived her trampled rights. Islam has used any opportunity and effective factors to achieve this goal and defend the right, personality and humanity of women that naming one Sura with the name of women is one of these factors and indicates the high position of women in the Islam and it suggest to the Islamic society that women like man, has superior human value and position and servant of God and even she can be one of the elect people by God (Asrar, 2011).

\section{Introduction of Nisa Sura}

Nisa Sura has 176 verses and it is revealed in the Medina when the prophet (peace be upon him) was establishing the Islamic government and healthy human community. For this, most regulation which are effective in the healthy community revealed in this Sura. The reason for choosing the name "Nisa" (women) for this Sura is that it is about the right of woman and the relationship of woman with man and other different aspects of woman life.

The word Nisa (women) has been used 20 times in this Sura. Nisa means women and majority of juridical decrees for the women are presented in this Sura; therefore, it is called Nisa.

Nisa Sura is the fourth Sura in Quran. Readers in Kufa consider it 176 verses, readers in Syria 177 verses and other readers as 175 verses that the first view is popular. This Sura has 3764 words and 16328 letters. The other name of this Sura is "Nisa-al-Kobra" and it is about juridical decrees for women and has one verse for oath (Asrar, 2011).

Since various discussion presented about the rights and decrees for women in this Sura and their rights protected and prevented any harm to them and since first 35 verses of this Sura is about family issues, it is called Nisa (women) (Makarem Shirazi, 1995).

\section{Types of Juridical decrees in Nisa Sura}

As mentioned, numerous juridical decrees are presented in the Nisa Sura that we can place them in two groups in a general classification: a) juridical decrees related to the family issues; b) worship, political, ethical and criminal decrees.

\subsection{Juridical Decrees Related to the Family Issues in the Nisa Sura}

\subsubsection{Family and Relationship between Husband and Wife}

Holy Quran in the verse 134 Nisa Sura specifies that patronage belongs to men and says "men are patrons of women. This verse does not mean dictatorship and oppression, but it means regular organized leadership regarding the responsibilities and consultations. The next verse which consists of two parts, says in the first part that this patronage is due to the superiorities that God has provided for some relative to others (regarding society system) (Qerati, 2004).

The verse 35 in the Nisa Sura points to the conflict between husband and wife says: And if ye fear a breach 
between them twain (the man and wife), appoint an arbiter from his folk and an arbiter from her folk. If they desire amendment Allah will make them of one mind. Verses 34 and 35 refer to the disobedience of women but in verse 128 it refers to the disobedience of man and says: If a woman feareth ill treatment from her husband, or desertion, it is no sin for them twain if they make terms of peace between themselves. Then emphasizes that peace is better. Although this short and meaningful sentence is about the family conflicts in this verse, but it is clear that it expresses a general rule that everywhere, the first principle is the peace, friendship and agreement and conflict is against the nature of human and his relaxing life and it should not be used except when necessary (Qarati, 2004).

\subsubsection{Marriage Decrees}

In discussion about the marriage, in part of verse 24, it refers to the temporary marriage ad says: And those of whom ye seek content (by marrying them), give unto them their portions as a duty. In the verse 25 , it presents the condition for marrying maids. First it says: And whoso is not able to afford to marry free, believing women, let them marry from the believing maids whom your right hands possess. Then says Allah knoweth best (concerning) your faith and since some people were not willing to marry maids, Quran says: Ye (proceed) one from another and you should not abominate their marriage. Then, refers to one condition of this marriage and says: so, wed them by permission of their folk. and in the next sentence says: give unto them their portions. This means that they should have suitable portion. Also it means that slaves can be owner of the properties that they acquired in legitimate way. Another condition of this marriage is selecting maids who being honest, not debauched nor of loose conduct. In verse 28 it says: Allah would make the burden light for you and for its reason says: for man was created weak and he should have legitimate ways to meet his needs in order to save himself from deviation.

Another juridical decree in the Nisa Sura is the problem of incest. Quran in Nisa Sura and in verse 22 refers to it and invalidates one of obscene practices in the ignorance era and says: And marry not those women whom your fathers' married $^{16}$ (Makarem Shirazi, 1995).

In verse 23 , about the women that marrying with them is forbidden, it refers that confidentiality occurs in three ways:

1) Birth which is called relative relationship.

2) by marriage which is called causal relationship.

3) Through breast-feeding which is called foster relationship.

First, it refers to relative confidants who are 7 groups and says: Forbidden unto you are your mothers, and your daughters, and your sisters, and your father's sisters, and your mother's sisters, and your brother's daughters and your sister's daughter (Tabatabaee, 2005).

Then it refers to the foster confidants and says: your foster-mothers, and your foster-sisters and in the last step, it refers to the thirds class of confidant and introduces them under several title:

1) Your mothers-in-law

This means that when a woman married a man, her mother, mother of her mother and so were haram for the man.

2) And your step-daughters who are under your protection (born) of your women unto whom ye have gone in. Then emphasizes that: but if ye have not gone in unto them, then it is no sin for you (to marry their daughters).

3) The wives of your sons who (spring) from your own loins.

In fact, the phrase "from your own loins" invalidates one the wrong rituals in the early Arab community.

4) And (it is forbidden unto you) that ye should have two sisters together.

In the verse 24 of this Sura, it follows the previous verse about the forbidden marriage and adds that: and all married women (are forbidden unto you).

\subsubsection{Women's Portion}

Portion as a social support for woman is one of the decrees referred to in Nisa Sura. In the ignorance era, because women have no value, their portion was given to her parents and considered it as their absolute right. Sometimes the portion of woman was given as a portion to another woman. Islam made void all these rituals and dedicated portion to woman as an absolute right (Motahari, 1998).

In the verse 4 of this Sura, following the discussion about choosing the wife, it refers to one of the absolute rights of women and emphasizes that: And give unto the women (whom ye marry) free gift of their marriage portions ${ }^{24}$. 
The verse 20 refers to the protection of other part of women's right and says: And if ye wish to exchange one wife for another and ye have given unto one of them a sum of money (however great), take nothing from it.

\subsubsection{Justice among Wives in the Polygamy}

In all religions, marriage is accepted and each of them has a kind of marriage. As prophet (peace be upon them) has said: there is a type of marriage for each ethnicity (Hor Ameli, 2008). Polygamy was common before Islam in many countries including Saudi Arabia and Islam could not eliminate it in one time, but it has imposed constraints, systems and criteria and determined conditions for those who had several wives in order to support women and prevent misuses in polygamy system. Islam limited number of wives to 4 and put an important condition for polygamy i.e. observing the justice. Holy Quran in the verse 3 of Nisa Sura says: and if ye fear that ye cannot do justice (to so many) then one (only) or (the captives) that your right hands possess. Thus it is more likely that ye will not do injustice.

\subsubsection{Decrees of Adultery and Chastity}

The verse 12 of Nisa Sura refers to the punishment of married women who commit adultery. First it says: As for those of your women who are guilty of lewdness, call to witness four of you against them. Then says: And if they testify (to the truth of the allegation) then confine them to the houses until death take them. Therefore, sentence for adultery by married women is life sentence. Then says: or (until) Allah appoint for them a way (through new legislation). This means that this decree is temporary. In verse 16 it expresses the decree of adultery for those men and women who have not spouses and says: And as for the two of you who are guilty thereof, punish them both. The punishment in the verse is a general sentence and verse 2 of Noor Sura determines the 100 lashes for parties which is an interpretation and explanation for this verse.

\subsubsection{Inheritance}

One of the juridical decrees that Nisa Sura has dealt with it and emphasized it is inheritance and dividing it among heirs. The most important issue in this Sura is inheritance of women.

In the verse 11 of this Sura, the decree for the first group of heirs (children, fathers and mothers) is expresses.

Quran, in the verse 12 of this Sura, explains the inheritance of husband and wife and says: And unto you belongeth a half of that which your wives leave, if they have no child; but if they have a child then unto you the fourth of that which they leave.

And in the case of inheritance of wife from husband says: And unto them belongeth the fourth of that which ye leave if ye have no child, but if ye have a child then the eighth of that which ye leave. Quran again in the verse 176 determined the legacy of brothers and sisters.

\subsection{Juridical Decrees Related to the Religious, Political, Ethical and Criminal Issues in the Nisa Sura}

\subsubsection{Imamat and Leadership}

The verse 59 and several next verses discuss about one of the most important Islamic issues i.e. leadership and determine real authority of Muslims in different religious and social issues. First it guides people to faith and says: O ye who believe! Obey Allah. Shia commentators have consensus in this regard that people who have authority in the verse 59 are imams that financial and intellectual leadership which all issues of life are delegated to them by God and prophet. The verse 60 complements this verse because in it, believers are invited to obey God, Prophet and authorities and arbitration of Quran and tradition and prevents obeying false deities.

\subsubsection{Prayer Decrees}

In verse 01, Nisa Sura referred to this issue and about the prayer of traveler says: when you travel, it is no problem that reduce the prayer, if you fear idolaters because they are your absolute enemy.

In verses about Jihad, the verse 102 educates the quality of fear life which shall read in the war.

From verse 43, we reach to several Islamic decree:

A. void prayer during intoxication;

The verse says: O ye who believe! Draw not near unto prayer when ye are drunken, till ye know that which ye utter;

B. void prayer during pollution;

As Quran says: nor when ye are polluted 


\subsubsection{Justice and Arbitration}

Verses of Nisa Sura are revealed in order to establish a healthy community and for this reason, problems of era before Islam and violations of that time were eliminated among new Muslims to provide a ground for a healthy community. In verse 65, God swore that: But nay, by thy Lord, they will not believe (in truth) until they make thee judge of what is in dispute between them. Then says: find within themselves no dislike of that which thou decidest, and submit with full submission.

\subsubsection{Punishment of Murder}

Another juridical decree in the Nisa Sura relates to the murder and its punishment. Because previous versed give freedom to Muslim for fighting against enemies and hypocrites, in order that no one misuses the law and retaliate his enemies, this verse and next verses have expressed the murder decrees. In verse 92 says: It is not for a believer to kill a believer unless (it be) by mistake (Montazeri, 1998, p. 345).

After expressing the mistake murder punishment, in verse 93, refers to the punishment of someone who has killed a believer and mentions four punishment and says:

1) Whoso slayed a believer of set purpose, his reward is hell for ever.

2) Allah is wroth against him.

3) He hath cursed him.

4) Prepared for him an awful doom.

\subsubsection{Repentance}

In verse 17, it expresses part of repentance conditions and says: Forgiveness is only incumbent on Allah toward those who do evil in ignorance.

In verse 18, it refers to those that their repentance is not accepted and says: The forgiveness is not for those who do ill-deeds until, when death attended upon one of them, he said: Lo! I repent now.

In verse 31 explicitly says: If ye avoid the great (things) which ye are forbidden, we will remit from you your evil deeds and make you enter at a noble gate.

The verse 48 says: Lo! Allah forgives not that a partner should be ascribed unto Him. He forgives (all) save that to whom He will. Whoso ascribed partners to Allah, he hath indeed invented a tremendous sin.

\subsubsection{Reproach}

In verse 148 and the next verse, it refers to some ethical commands of Islam. First it says: Allah loved not the utterance of harsh speech save by one who hath been wronged.

In the verse 149, it refers to opposite point and says: If ye do good openly or keep it secret, or forgive evil, lo!

\subsubsection{Accusation}

In verse 112, it refers to the importance of accusing innocent people and says: And whoso commits a delinquency or crime, then throws (the blame) thereof upon the innocent, hath burdened himself with falsehood and a flagrant crime.

\section{Migration}

Following the discussion about those who suffer problems because they do not migrate, the verse 100 refers to the importance of the migration: first, it refers to the effects and advantages of migration in this life and says: Whoso migrates for the cause of Allah will find much refuge and abundance in the earth, and whoso forsakes his home, a fugitive unto Allah and His messenger, and death overtakes him (Tabatabaee, 2005, vol.5, p.452). Then, it refers to the spiritual aspect of migration and says: Whoso migrates for the cause of Allah will find much refuge and abundance in the earth, and whoso forsakes his home, a fugitive unto Allah and His messenger, and death overtakes him, his reward is then incumbent on Allah. Allah is ever Forgiving, Merciful. Therefore, immigrants achieve victory in both cases. It is interesting that migration, not for saving individual, but for saving Islam, is the origin of Muslims' date and forms the foundation of all political and social events and in each time and period it occurs, Muslims are obliged to migrate (Mohammad-ibn-Ali-ibn-Babvooyeh, 1413AC, p. 342).

\section{Conclusion}

In addition to that Nisa Sura name is taken from the word women, it expresses the decrees related to the women and it has numerous juridical decrees. Another characteristics of this Sura is that it has oath verse and in verse 65, by taking oath to God, emphasizes on the obstinacies of idolaters that a group of people are stubborn such that 
they do not accept the truth with any reasoning and trying to guide them is waste. In fact, this Sura is one of the juridical Sura in Quran, especially for women and for this reason, it is called Nisa (women) and the main theme of this Sura is legislation (Qomi, 1988, vol.2, p. 215) and its general points are:

1) Decrees and social and human rights of women including polygamy, observing the rights of women in polygamy and some decrees for marriage and plans for public chastity. Also the non-obedience and conflict between husband and wife and resolving the family conflicts and divorce considered in this Sura (family and civil courts).

2) Decrees related to the support of those who need help, like orphans and derelicts and required commands for maintaining and preserving their rights. Also decrees about incapacity and incapable people, i.e. those who cannot manipulate their assets and social cooperation, helping parents, relatives, neighbors and deprived people (Tabatabaee, 2005, vol.4, p.324).

3) Heritage decree and dividing the properties of deceased person among the heirs and relatives and in fact, inheritance law is based on the natural and fair method against the bad form common on that time and they deprived poor people with different excuses (Makarem Sgirazi, 2005. Vol.3, p.242-243).

4) Some juridical decrees about the assets and properties, business and trade decrees and decrees about preserving public assets (Hashemzadeh, 2006, p. 152).

5) Introducing enemies of Islamic community and alert to Muslims. Necessity of military preparedness, mobilization, military organization, mental and spiritual power, patience and resistance against enemy.

6) Islamic government and necessity of obeying leader of this government.

7) Invitation to faith, justice and cutting the friendly relationship with enemies.

8) Importance of migration and necessity of it.

9) Developing social justice and fairness and fighting against oppression and inequality.

10) Avoiding accusation to innocent people and reproach because God hides the defects and wants that believers follow this decree.

11) Part of fate of ancestors for higher familiarity with fate of unhealthy communities for example, story of Moses or Jesus (peace be upon them) 9Qerati, 2004. Vol. 2, p.237).

And other cases like advising prayer and fear prayer and etc. This Sura begins with piety and blessing of being and creation and ends with a financial issue related to the legacy and knowledge of God about the benefits of decrees. It means that it begins with the problem of piety and spirituality and ends with an economic problem and ties spirituality and economy to each other to understand this reality that economy and spirituality are both required for the society and both are needed for the survival and are development factors for Islamic community, but piety and spirituality are first as the purpose and foundation but economy is at the end as superstructure (Foladvand, 2002, p. 535). Considering decrees' philosophy has significant influence on the Ijtihad. We should pay attention to the importance of beliefs and external information in the interpretation of Quran verses and the role of time and place in the inference of decrees because some decrees in Quran are revealed in a certain time and they are not common today. According to most of scholars, Islam and especially Shia has dynamic jurisprudence; this requires people to modernize the juridical decrees in Quran for the complex life of modern human and identify the dynamic nature of Quran. Regarding this:

1) crucial attention to the scientific communities including university to the role of decree verses: it is necessary to write books with new language and classification of decrees' verses and teaching it in the universities and publicizing these findings because Quran is the first and last step of recognizing the decrees and Islam teachings and until these decrees are not known yet, other juridical books cannot use and it is better that students and people become familiar with regulations and decrees...

2) There are some decrees in the Nisa Sura that relate to the ignorance era and people, while this is the outward meaning of the verse but the real meaning of it should be identified and used and this is the duty of scholars and commentators.

3) Unfortunately, sometimes it is seen that judges and decree executors act beyond the law of God. While juridical decrees are very clear in this regard. Therefore, judgement and arbitration based on the personal and wrong perception of these decrees is a great oppression to Holy Quran.

4) Nisa Sura is known as decrees' Sura but it seems that media and even commentators of religion, not only have not familiarized people with this Sura but this Sura is the origin of most criminal regulations in the country. 
Therefore, if this Sura is known by people, by increasing the awareness of people to criminal, ethical and jurisdictional crimes, the rate of crime decreases and this is possible when the legislator does not violate the law.

\section{References}

Asrar, M. (2011). Quran teachings. Qom. Noor Publication.

Fooladvand, E. (2002). Holy Quran. Soroush Publication. Tehran.

Hashemzadeh, M. A. (1995). Bibliography of Quran decrees based on the century. No.3. p. 165-184.

Hor Amili, M. (2005). Vasayel-al-Shia. Tehran.

Makarem Shirazi, N. (1995). Nemouneh interpretation (1st ed.). Tehran.

Montazeri, H. (1999). Hudud. Dar-al-fekr. Qom. Thought publication.

Mottahari, M. (1999). Collection of books. Woman right system in Islam. Sadra publication. Tehran.

Noori, H. (1407). Mostadrak-al-vasayel. Qom.

Qerati, M. (2004). Noor commentary (11th ed.). Tehran.

Qomi, A. (1988). Qomi commentary (4th ed.). Qom. Dar-al-ketab.

Tabatabaee, S. M. H. (2005). Al-Meizan-fi-Tafsir-al-Quran (9th ed.). Translated by Mohammad Bagher Mousavi Hamadani. Qom. Islamic publication.

\section{Copyrights}

Copyright for this article is retained by the author(s), with first publication rights granted to the journal.

This is an open-access article distributed under the terms and conditions of the Creative Commons Attribution license (http://creativecommons.org/licenses/by/4.0/). 